\title{
Investigation Into Motivation Types of Saudi and Chines EFL Learners and Gender Role Differences
}

\author{
Asma Alqahtani ${ }^{1}$ \\ ${ }^{1}$ English Language Institute, University of Jeddah, Saudi Arabia \\ Correspondence: Asma Alqahtani, English Language Institute, University of Jeddah, Saudi Arabia.
}

Received: October 6, 2021

Accepted: November 22, 2021

Online Published: November 26, 2021

doi: $10.5539 /$ elt.v14n12p101

URL: https://doi.org/10.5539/elt.v14n12p101

\begin{abstract}
This study investigates motivation types of Saudi and Chines EFL learners and gender role differences. I selected these two groups because they constituted the most dominant groups that study English abroad. The descriptive and correlational approaches were used to examine the participants' motivation by collecting the data through questionnaire and interviews. Twenty-five Saudi and Chinese college level English language students were selected as samples for collecting data for answering the research questions. The findings showed that both groups have extrinsic and intrinsic motivation as well integrative and instrumental motivation. The Chinese group's intrinsic motivation is stronger than the extrinsic motivation.
\end{abstract}

Keywords: second language learning motivation, second language acquisition, Saudi and Chinese motivation differences

\section{Introduction}

Motivation is one of the significant factors that facilitate learning a second language. Learners' motivation is a crucial aspect in learning the second language, however, which type of motivation that students have and obtain is the driving force to sustain the long learning process. Motivation is identified primarily with the learner's orientation toward the goal of learning a second language. In the second language field, motivation can be distinguished as the following types: Integrative, Instrumental, Extrinsic, and Intrinsic motivation.

Learners' goals from learning a second language (L2) differ widely from person to person. Many learners might learn the second language for the pure intrinsic enjoyment, while some learners may learn L2 to obtain the extrinsic reward of a university admission or another goal. Learners' type of motivation specifies their goal of learning a second language, which facilitates teachers' mission and enables learners to specify their needs that help them to achieve their goals.

Understanding why individuals carry out a particular motivation and what their motivation is oriented toward are two of the most important theoretical and empirical foci of motivation researchers. Saudi Arabia and China are the main countries that teach English a s foreign language and they are the main countries that send their students abroad to study and learn English. ESL/ EFL English teachers are in very bad need to know more about the type of motivation of each group and know more about the differences of each group, "this is a curious state of affairs since motivation is a widely recognized variable of importance in SLA, and perhaps one of the key factors that distinguishes first language acquisition from second language acquisition processes" (Ushioda, 2010, p. 5).

EFL/ESL teachers and instructors need a deep investigation regarding Saudi and Chinese types of motivation, their group differences, and their gender differences in order to deal with them significantly and to facilitate teachers' understanding of ways that increase their motivation. This study is an investigation into motivation types and gender role motivation differences of Saudi and Chinses ESL learners. The descriptive research questions proposed are:

1) What type of motivation do ESL learners (Saudi and Chinese) have for learning a second language?

2) Are there any differences among different groups of students?

3) Are there any differences between male and female students of each group? 


\subsection{Research Design}

Before conducting semi-structured interviews, a survey was first given to gather complementary data for the following advantages: survey questionnaire data might provide noteworthy or surprising results to follow up on interviews. A survey questionnaire would afford a means to select interviewees based on the learners' questionnaire answers. The participants were Saudi and Chinese EFL learners. Additional details about interviewees' selection criteria can be found in the methodology and data analysis.

\section{Literature Review}

\subsection{Motivation Types}

\subsubsection{Instrumental and Integrative Motivation}

Motivation is considered one of the significant factors that prompt second language learners to achieve a high level of proficiency. Motivation is identified primarily with the learner's orientation toward the goal of learning a second language. In most cases, learners' goals of learning define their types of motivation. Gardner (1972) has developed the term of integrative motivation. Besides, he believes that it is the most effective type of motivation. Integrative motivation refers to the second language learners' desire to be a member of the target language society and to build relationships with the second language (L2) society members. He indicates that, "some early studies upheld the relative importance of the integrative orientation" (e.g., Gardner \& Lambert, 1995). Others did not support the model, "because the instrumental orientation predicted L2 outcomes" (Noels et al., 2003, p. 36). On the other hand, instrumental orientation describes the reasons for L2 learning that is related to the potential pragmatic gains, such as obtaining a university admission. Learners who have integrative motivations are more likely to be highly proficient in the second language due to their effort in learning L2 which enables them to succeed in achieving their goal.

Sultan and Husain (2010) suggest, "although both types of motivation are vital for the acquisition of a second language, integrative motivation is generally found to be more effective as compared to instrumental motivation." (p. 85). However, as mentioned in Zhao (2012), Dörnyei proved that instrumental motivation is considered an important type of motivation as well. As well, Sultan and Husain (2010) study examines the connection between motivational factors in terms of instrumental and integrative motivation with the second language acquisition (SLA). They investigate which type of motivation could be more effective in acquiring a second language. They collected data from a sample of 234 university students in Pakistan by utilizing instrumental and integrative motivation scales. The result reveals that students who obtain instrumental motivation toward learning L2 are higher achievers than those who have integrative motivation. In this study, they indicate that, "the students who were not motivated instrumentally exemplified the view that they did not consider and value English as a crucial element for the success in their lives" (p. 151). Instrumental motivation makes second language learners learn the language with a great enthusiasm, particularly, when they value the return on investment.

\subsubsection{Intrinsic and Extrinsic Motivation}

Another type of motivation is intrinsic motivation which refers to the pleasure and the enjoyment that accompanies the learner when learning the second language. This type of motivation rose due to the globalization of English. Most movies, games, and songs are showed in English language which makes learning this language pleasurable for most learners. As mentioned in A. Noels et al. (2003) "one formulation that has received the attention of several scholars is the distinction between intrinsic and extrinsic motivation (e.g., Brown, 1994; Dickinson, Noels, Pelletier, Cle'ment, \& Vallerand, 1995; Dornyei, 1994a; Schmidt, Boraie, \& Kassabgy, 1996; Burden, 1997) (p. 37). The last motivation type is extrinsic motivation which refers to learners' execution of an activity for its innate gratification where learning L2 are instrumental to some consequence. As Zhao (2012) mentioned in his study, learners who extrinsically motivated are, "may work efficiently in the short term in response to external rewards and incentives, but their motivation is unlikely to sustain itself autonomously if the learning experience does not generate internal or intrinsic rewards" (ibid.22). According to Kang (2000), L2 learning orientations, in settings where most learning of the second language takes place in the teaching environment, might consist of sub- components of Gardner's traditional intrinsic/extrinsic orientations as well as integrative/instrumental orientations, depending on the contexts.

\subsection{Factors Influenced Learners' Motivation}

\subsubsection{Chinese English Learning Background and Motivation}

Teaching English in China has become a basic need to promote scientific, technology, and commerce advance, "the Chinese government has paid much attention to English learning and teaching since 1978, when an open 
door policy with the outside world was introduced to rejuvenate the economy" (Siemon, 2010, p. 39). In China, parents exert immense effort to teach their children English because they consider it the base to get a job or to gain a university admission to study abroad or for immigration issues. There are a huge number of Chinese immigrants around the world and the number of immigrants is annually growing. In China, teaching English starts from first grade in large cities, but in small towns it is taught from third grade. In high school, English is taught an average of 4 or 5 hours a week. Teachers make students depend mainly on memorization of everything they learn in English class and memorization is regarded as an important skill. They memorize vocabulary and grammar; however, they are unable to use them appropriately in speaking or writing. In high school, students are expected to graduate from the school with mastering 2000 English words.

After they graduate from the high school, students are supposed to pass the College English Test Band 4 (CET-4) which is designed for non-English major students who want to get a university admission like "in China, a common phenomenon in college or university is that some students though very excellent in learning all major-related subjects are not interested in learning English at all, and can't get the bachelor degree because they fail to pass CET-4 while this certificate is absolute for the degree" (ZHOU Wan-er, 2008, p. 7). However, this reason makes Chinese students obtain extrinsic motivation rather than intrinsic motivation. ZHOU Wan-ers study asserts that, "those who study English in order to pass the CET-4 examination to get a good job after graduation are extrinsically motivated. Usually, after they pass the CET-4 examination, such motivation will vanish" (p. 7). This declares that extrinsic motivation doesn't have the great impact as intrinsic motivation. On the other hand, in China, "English learning strategies are primarily focused on reading and writing, on grammar and translation, and on memorization of vocabulary" (Siemon, 2010, p. 40) which make them lack "the ability to use the target language for authentic communication" (Hu, 2002, p. 93). This traditional method of teaching is no longer sufficient due to its effect upon L2 learners' speaking skills. Therefore, it can be inferred that English learning background can affect the learners' motivation. Liu (2010) investigated the motivation in Chinese students to learn English after they finished school and enrolled in university. He explored the general pattern of motivation in Chinese university EFL learners. He used reflective journal entries and a survey to examine their motivation. The result of this study reflects that the main aim for Chinese students to learn English is "to find a job, pass exams, to improve English, and to communicate with foreigners, English is a beautiful language and learning the language was fun" (p. 30). Also, Chinese have high instrumental and integrative motivation toward learning English. Moreover, motivation has something to do with the learning setting. In China, English is learnt as a foreign language. Therefore, many students mainly have instrumental motivation, but if they are well guided, they will progress greatly" (ZHOU Wan-er, 2008, p. 8).

In a study done by Qian (2018) reviews the challenges facing EFL motivation in China and the discussion of possible Solutions found that instrumental motivation, self-efficacy, autonomous extrinsic motivation, attitudes to learning English, ought-to L2 self are proven to be effective and can serve as positive motivations. Based on these, suggestions to teachers, parents and schools are given to improve the language learning efficiency which can lead us to consider the context of teaching English in China. Teaching English as an EFL language has an impact on the learners' type of motivation. However, another study stated a different result about Chinese motivation types." Li study (2006) conducted a study to examine the Chinese motivation to learn English. He indicates that, "Chinese believed that learning English was important; their main goal orientations were instrumental and extrinsic" (p. 15). In China, English learning leads the students to obtain instrumental motivation rather than integrative or intrinsic motivation because of the lack of the interaction in the second language.

Lei, Z (2012) examined factors that influence their motivation as well as the types of Chinese college non-English majors' English learning motivation. He found that learners learn English because they are mainly directed by external influences which may work efficiently in the short term but are unlikely to stand the motivation in the long run. Moreover, the investigation displays that both internal and external factors are considered as the important aspects to enhance learners' motivation.

\subsubsection{Saudi English Learning Background and Motivation}

As mentioned in Maherzi (2011) Al-Seghayer illustrates that English is considered as an instrumental medium of learning at various stages in the Saudi educational system. English was introduced by the government shortly after the establishment of the Kingdom in 1932, so that citizens learned how to communicate with the outside world. English is the only language that is taught in Saudi Arabia and in some universities French and Chinese languages are taught as elective courses. In 1960, English was introduced as a core course in the intermediate schools. Now, it is introduced in elementary and taught for 45-minute periods (four hours) weekly for the intermediate and high school as well, "although the Ministry of Education decided to implement the English 
curriculum at the elementary level beginning 2002-2003, to improve Saudi students' proficiency level, English was still introduced only in intermediate, compared to being a required subject for KG levels through grade 12, in both Saudi private schools and international schools" (Maherzi, 2011, p. 770).

In addition, Al-Seghayer (2005) indicates that while concentrating on the four skills (listening, speaking, reading, and writing), the goal of teaching English is to provide the students with the general knowledge about English to use it to communication with the outside world or in some aspects of daily life. Recently, with the 2030 vision the number of students who are studying abroad have significantly increased. English became an important factor for learning multiple sciences and a potential factor to study abroad. Saudi Arabia noticed the need for the English language which drove them to work hard to rectify the gap of teaching English in Saudi Arabia. Moreover, "in a globalized world where English has become a global language, many people - including Arabs currently feel that English is superior to all other languages - including Arabic. Many young people have become keener on learning English" (Al-Jarf, 2008, p. 189). Maherzi (2011) studied the classroom climate and motivation to study English in Saudi Arabia. The result of this study reflects that since English in Saudi Arabia is taught as a foreign language, the teacher is the students' link to practice English in class. The students develop self-determined forms of motivation (intrinsic motivation) through autonomy-supportive classroom climate.

In a study done by Daif-Allah and AlJumah (2020) to explore the differences in motivation to learn English among Saudi university students revealed there are significant differences in students' motivation because of the differences in their academic backgrounds.

Moreover, Al-Mubireek (2020) investigated student motivation in terms of three motivational constructs: instrumental, integrative, and personal. It explored learners' attitudes towards the use of English language in Saudi educational and social contexts, the English language itself, and the culture of the English-speaking world. This study found that learners in different majors and at different levels of proficiency may benefit from a greater focus on internal factors such as attitude and motivation.

\subsection{Gender Role}

There is a clear and proven difference between genders in their ability to learn a second language. There are many factors that contribute to these differences such as the fact that girls talk before boys and the average of words that a girl of two years old has is more than the average of words of a boy the same age. Females tend to master spelling and grammar skills more than males do. This reason may enhance females' motivation to learn languages more than boys. Kissau's (2006) study reveals that many Canadian researchers suggest male students are lacking the motivation to learn French. These differences lead females to acquire the second language faster and more superior than males do which lead researcher and scholar questioning whether children should be schooled separately in single-sex classes and whither the language learning differences innate or a result of other social factors.

Motivation has been contrasted with gender as another instance of differences between males and females. These language differences affect learners' motivation to learn a second language as well as other social and cultural factors. Plat (2011) posits that higher levels of motivation are testified by females. Also, Kissau (2006) study declares that female university students of German in the USA were able to express and pronounce second language more than males and were able to satisfy teachers in their performance in L2. The findings show that "while gender differences were consistently found in regard to a number of classroom-related factors, the qualitative data often suggested that the impetus behind such gender differences was societal in nature" (p. 88). However, cultural gender differences play a role to motivate learners. Extreme politeness in both Chinese genders alters their motivation in learning L2 or reduces it. On the other hand, Saudi students' cultural factors play a role to define motivation in females' case. Polat's (2011) states that, "in multicultural settings where gendered socialization patterns are constituted within multiple dominant and subordinate ethnic and cultural power relations, differences in affective factors between women and men are unavoidable" (p. 34). The education system in Saudi Arabia implements its gender-segregation rule in academic institutions across the country which makes them anxious when studying abroad in mixed gender classes. These factors might define the types of motivation in Saudi female ESL/EFL learners. The cultural setting assists in determining two components; firstly, the type of orientation which students will have, and secondly which is more valued in language learning.

Batubara et al. (2020) conducted a gender-based study to evaluate students; motivation to learn English as a foreign language. They found that various factors influenced English learning motivation such as empowerment, usefulness, success, interest, and caring. They pointed out that female learners experienced low levels of these factors as compared to male counterparts. 
Also, Daif-Allah and AlJumah (2020) founds that gender differences in overall motivation were also found between male and female computer science students in favor of females who seem to make more effort and have a higher perception of the valence of learning English than male students. Moroevoer, Alresheedi (2014) investigated, through quantitative surveys, the types of motivation influencing 75 Female Saudi undergraduate university students to learn English and found that although the average scores for each type of motivation being tested were similar, the results showed that these students were primarily motivated by instrumental and intrinsic types of motivation.

However, generally many studies reveal that females are more motivated than meals like, Williams, Burden and Lanvers (2002) study illustrates noticeable differences between females and males who were learning French and German. Females were highly motivated than male. Motivation has traditionally been classified as an affective variable in SLA, and "it might be assumed that one reason why motivation research has remained somewhat outside the central concerns of SLA is because of SLA's predominant focus on language learning as a cognitive psycholinguistic process" (Ushioda, 2010, p. 10). There is a small amount of research that examines Saudi and Chinese motivation differences. However, there is no research that investigated the Saudi and Chinese motivation types differences considering the gender role. Regarding the issue of gender role in motivation of different groups and the types of motivation of different groups, specifically Chinese and Saudis as the largest groups of EFL learners, this study tackles these issues due to their importance in the second language field.

\section{Methodology}

This study was conducted an ESL institute in the U.S. The participants of this study were 25 ESL students, 13 female and 12 males. They took the TOFEL placement exam, when they came, and they placed in level 3 in the institute which is considered beginner level. Their scores on placement TOFEL test range from 300 to 350 . The participants were from China and Saudi Arabia, and they are newcomers to the U.S. Most of the Saudi participants have scholarships form their jobs in Saudi Arabia as they work as lecturers or graduate assistances. I used Skype to interview the participants after sending them the survey via emails.

This program aims at preparing students for university study, and to reduce the knowledge gap between the graduates of public education and what is expected of a student performance at the undergraduate level by teaching them the English necessary for university study. By participating in and completing the courses throughout this year, students can be more easily accepted into the degree program of their choice in different majors. In the preparatory year, students study English language and study skills up to the required level for progression onto undergraduate and graduate study. Both groups study English to enroll in their desired majors after they finish.

A survey was adopted to collect the data which was designed based on measuring the participants' motivation types. I have translated the survey into the Chinese and the Arabic language as shown in appendix 1 because the participants are still novices. The number of the survey items were 28 and the items wording was modified to suit the students' responses. Participants were asked to rank the statements on a four-point scale ranging from "strongly disagree" to "disagree" agree "strongly agree", which measures the degree to which the participants agree with those statements. The first section of the survey contained items that were ordered to measure the participants' intrinsic motivation. The next nine items were designed to measure their extrinsic motivation e.g. "because it will help me to get a university admission", twelve items represent the instrumental motivation e.g. "because it will help me if I should ever travel", and four items represent the integrative motivation "because I am eager to build relationship with native". Moreover, an interview was adopted mainly to explore gender role motivation differences of each group and the type of motivation that participants hold in learning the second language. The interview contained 10 questions about the aim of learning the second language, the cultural or other obstacles that affect their learning of L2 and whether it has an impact on their motivation. Also, the participants' learning background impacts upon them, and their attitudes toward the second language. The questions of the interview were designed as open-ended questions in order to give the participants the space that they need to elaborate in their answers. There were 15 questions, four warm-up questions and 11 follow-up questions. The interview took 25 minutes with each participant.

The data of this study was analyzed using statistical procedures. In addition, I have transcribed extracts from the interviews. Also, descriptive statistics including means, standard deviation, frequency, have been used to calculate the participants' responses. The interview and the survey were translated into Chinese and Arabic languages to assert the validity of the participants' responses. 


\section{Data Analysis}

\subsection{Participants Survey and Interviews}

\subsubsection{Chinese Student' Types of Motivation for Learning English}

What type of motivation do ESL Chinese and Saudi learners have for learning English is the point we are investigating here. There are many types of motivation such as extrinsic, intrinsic, instrumental, integrative motivation. We are analyzing which motivation Chinese students adopt more for learning English and their underlying factors influence their motivations. A questionnaire was designed to investigate and measure their types of motivation. There were 28 items in the survey classified to measure intrinsic, extrinsic, integrative, and instrumental motivation as shown in appendix 3 .

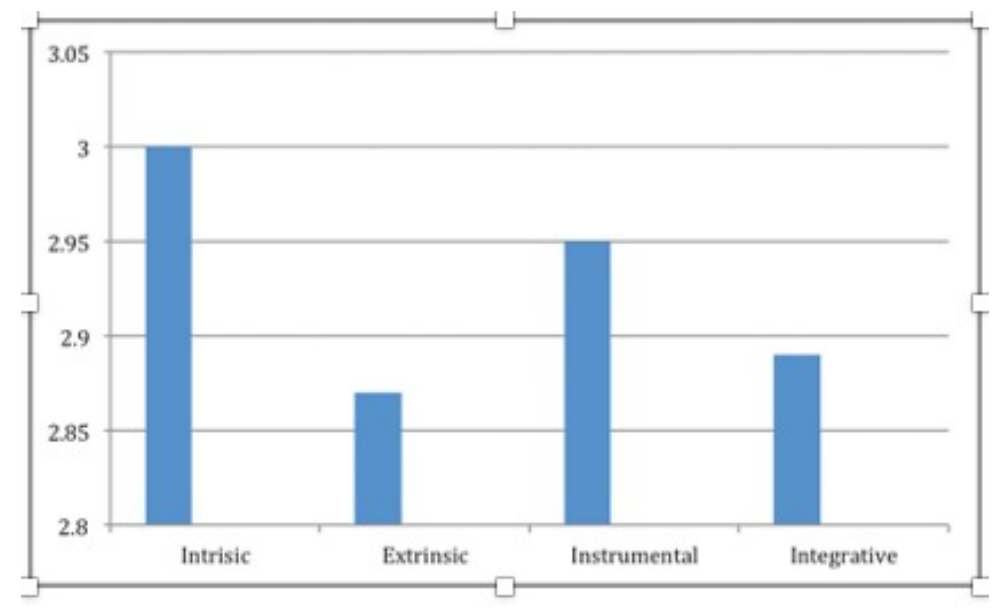

Figure 1. Mean Average: Chinese Motivation Types

The general mean for Chinese extrinsic motivation is $(2,87)$ and the general mean for intrinsic motivation is $(3$, 0 ) which represents that the Chinese EFL participants have both motivation types for learning English; however, the intrinsic motivation is slightly higher than extrinsic motivation. In the interview, one of the students indicates his agreement about the desire of learning English for intrinsic reasons. One student explained, "everything in the world makes me loves learning English, I like watching movies and shows in English which mainly makes me love learning this language".

His answer indicates his found interest in learning English language for intrinsic reasons rather than educational or other purposes. Also, I asked him about his background of learning English and whether it's now affecting his interest in learning English. He reveals that

"In China, I started learning English early in school and I was very happy to learn a new language. In class, I was very interested in the language however, they focused more in improving the writing skill and grammar more than any skills which a little bit disappointed me because I hate writing and I still now hate writing even though I am good writer and it that helps me a lot in the ESL classes and will help me at university".

His answer states that he has had a great fondness for learning English since childhood. The extensive teaching of writing and grammar demotivated him at the beginning at school. However, that motivates him to pursue learning English to achieve educational goals.

The Chinese learners need of English for every aspect in their lives enhances their intrinsic and extrinsic motivation. Also, their worthy background teaching of English by concentrating on the writing skill makes Chinese students' journey in learning English easier as they focus on improving their speaking skill. In addition, the data represent multiple different reasons for learning English. In Appendix 3 (items of intrinsic motivations), the item 4 and item $28(3,27)$ gain the same and the highest mean rating which indicate the student enjoyment of learning English because they like listening to songs and watching movies and shows in English which motivate them to learn the language for a new challenge in their lives. Chinese students' responses indicate that they can learn English with great motivation by listening to songs and watching movies. Item 5 gains the lowest mean rating $(2,36)$ which represents that English literature does not motivate learners to learn English. They show a low tendency for learning English because of the English literature. Item $1(2,9)$ low mean rating indicates that the fondness of English is not the reason that prompts the Chinese to learn English. 
Items of extrinsic motivation as shown in appendix 3 were designed to measure the extrinsic motivation of Chinese ESL learners' participants. Items of extrinsic motivation measure the desire of learning English to achieve a certain goal. Items 7, 8, 9 were ordered to measure the participants' desire of learning English to gain educational purposes. The item $7(3,09)$ gains the highest mean rating among these three items which indicates the driven desire to learn English is for gaining university admission. The item $8(2,72)$ explores low tendency for learning English to get high scores in the English subject after obtaining an admission and enroll to the university. Item $9(3,09)$ represents the participants desire to learn English to obtain far reaching goals, which was learning English to apply for post-graduate studies. Item $12(2,7)$ reveals that parents were not the main reason that drove the Chinese participants to learn English. Item 8, $(2,72)$ and $13(2,9)$ reveals participants after gaining their admission are not learning English for educational purposes. Item $21(3,36)$ shows the needs of learning English to communicate with the contemporary world which gain the highest mean rating among the extrinsic items, stating the need for English to deal with every aspect in life is the impetus for Chinese learners to learn English. In addition, item $15(3,36)$ the needs of English as an instrument when traveling abroad is one of the strongest reasons for the Chinese ESL students to learn English. Item $17(3,0)$ shows the Chinese agreement for learning English for immigration purposes. Items 20, $25(2,18)$ gain the same rating mean which implies that the Chinese desire behind learning English to make the world know more about China is not a significant reason for learning English for them and that they do not view English as a superior language. Building friendships with the members of the target language community is an important driving reason for the Chinese student to learn English as shown in item $16(3,18)$.

The items of this survey were categorized also from another perspective. The survey was also designed to measure integrative and instrumental motivation of the participants. The mean of the integrative motivation is 2 , 89 and the mean of the instrumental motivation is 2, 95. There is no clear difference between these two types; however, the instrumental motivation is higher than the integrative motivation. This represents that, although the participants indicate in item 20 that they agree to the importance of English as an indication for being well educated, they show slight desire to be integrated to the target community. The Chinese students, in their responses, clarify that the goal from learning English is more instrumental as shown in items 8, 9, 15, 19, 21.

They mainly learn English for instrumental reasons such as getting jobs, promotion, and traveling abroad. In addition, most of the Chinese students' answers in the interview indicate a strong motivation to learn English for intrinsic and integrative reasons. They want to learn English to achieve certain goals such as getting a job, gaining university admission, but they show a great attitude toward the second language community. They want to have good relationships with natives of the second language. Two of the male students show their strong attitude to integrate with the L2 community. Also, that they want to adopt English to be their first language and they want to be a part of the L2 community, "I like using English in everything in my life and I have planned to immigrate, also, I want to bring my family with me to live abroad forever".

\subsubsection{Saudi Students Motivation Types for Learning English}

The Saudi students' responses in the survey presented that, the general mean for the intrinsic motivation is 1,75 and the extrinsic motivation general mean is 2.81 which is higher than the intrinsic motivation as shown below:

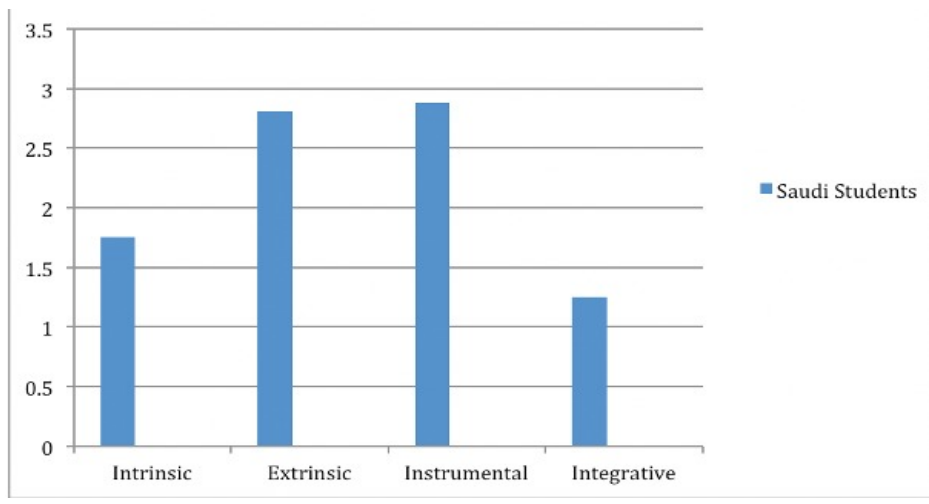

Figure 2. Mean Average: Saudi Motivation Types

Teaching English in Saudi Arabia affects their motivation to learn English. Teaching English in Saudi Arabia still needs major improvement because the students usually graduate from high school without a strong background in English which demotivates them. In addition, teaching English as a foreign language prevents students from communicating with other natives. These reasons make their motivation more extrinsic to achieve 
certain goals rather than intrinsic. The mean rating of extrinsic motivation is 2.81 which proves that as shown in appendix 3. The item 1 (2.66) and item 3 (2.77) represent the students' interest to learn English is low compared to item $4(3,44)$ which represents their enjoyment for learning English to listen to the English songs and watch movies. Items 5 and 26 gain the same mean rating $(2,11)$ which shows a low tendency to learn English for reasons such as interests in English literature or achieve great sense by learning English. For the extrinsic motivation which is obviously higher than the intrinsic motivation (2.81), the item 7 (3.22) gains the highest mean rating among other items that measure the extrinsic motivation. This indicates that Saudi participants believe learning English is the first step toward a successful academic life and to achieve goals like getting a high GPA to enroll to their desired majors at the university.

Item 16 (2.33) gained the lowest mean rating which shows that the studies' cultural and social status do not encourage them to build friendships with English native speakers. Also, social status plays a role, for example through the interview with one of the Saudi participants indicates that he doesn't contact with any English native speakers because she never travels abroad and most of her time spends it with her family. "Before enrolling to the university, I was interested very much to learn English to build relationships with native speakers online since I love games, but now I mainly learn English to pass the foundation year, I am not interested to learn the language like before, I don't have much time to learn English like before because I am with my family the whole day or at university".

In addition, Saudi culture prevent them from building relationships with other gender, which explain their attitude. Also, the social status plays a role, for example through the interview with one of the Saudi participants indicates that before he gets married, he was living in the dorms and he had to contact with other natives because he lives with them "I mainly learn English to gain good score in the TOFEL exam, I don't live in the dorms so I don't contact with natives in a regular basis".

Item 25 (2.88) indicates lower tendency to learn English to make people know more about Saudi Arabia. Item 18 (3.0) gains high mean rating compared to other items in the extrinsic motivation because in Saudi Arabia to get a high GPA in the foundation year, students must pass the English course with a high grade as it is taught for 18 hours per week. This explains their agreement about this item. In the interview one of the participant states that "I can pass any of the language exams, but I decided to study the English course in the foundation year to raise my GPA".

The survey items were also categorized from another perspective to measure participants' instrumental and integrative motivation as shown in appendix 7 and 8 . The general mean of integrative motivation is $(1,25)$ and the instrumental motivation general mean is (2.88). Obviously, the instrumental motivation is higher than the integrative motivation. This asserts that social status and cultural aspects play a role in Saudi learners' motivation. Also, their English learning background affects their motivation. In Saudi Arabia there is no strong teaching of the four skills in the school, which demotivate learners and make them adopt the instrumental motivation to achieve certain goals. Item $17(2,10)$ proves the lower tendency of Saudi to learn English for immigration purposes because there are no Saudi immigrants abroad. Because the economic position in Saudi Arabia is stable compared to other countries. Items 9 and 21 gain high means rating (3.11) reflecting the tendency of learning English to achieve far goals like pursuing postgraduate studies.

\subsubsection{Motivation Types Difference Between Chinese and Saudis EFL Learners}

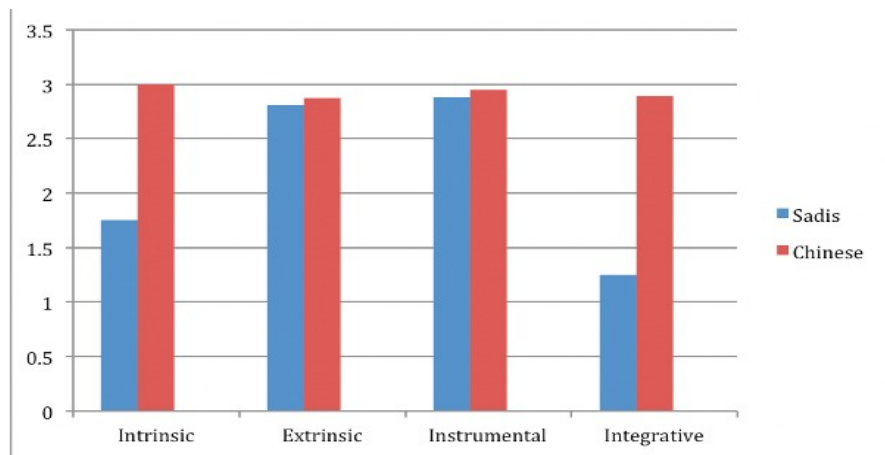

Figure 3. Mean Average: Saudis and Chinese Motivation Types

As presented above, Chinese intrinsic (3.0) and extrinsic motivation (2.87) are almost the same. However, Saudi students' extrinsic motivation (2.81) is higher than intrinsic motivation (1.75). The two groups have similar extrinsic mean ratings that are directed to achieve certain goals. On the other hand, there is a significant 
difference between the two groups' intrinsic motivations. The Chinese group's intrinsic motivation is higher than the Saudi group. Their Cultural differences and their English learning background differences play a role in defining their type of motivation. The freedom that Chinese enjoy compared to the Saudi students is an obvious clue to consider their intrinsic motivation differences. On the other hand, the integrative $(1,25)$ and instrumental motivation of the Saudi group (2.88) is differed from the Chinese integrative (2.89) and instrumental motivation (2.95).

\subsection{Saudi Females vs. Saudi Males}

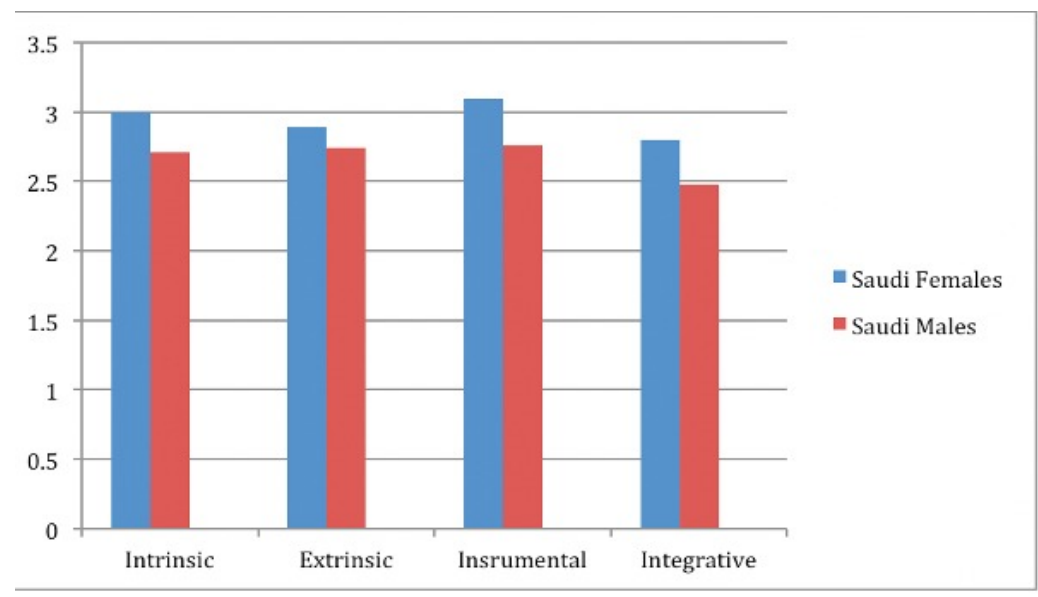

Figure 4. Mean Average: Saudi Males and Female Motivation Types

Saudi female intrinsic general mean measuring is 3.0 and the extrinsic motivation is 2.89 . The Saudi males intrinsic motivation general mean is 2.71 and the extrinsic motivation is 2.74 . In the interview with one of the Saudi female students, she indicated that, "I am working hard to improve my language to be a good mother and to teach my children in the future".

Her response states that the Saudi females are intrinsically and extrinsically motivated than the Saudi males. In addition, she added that "I am learning English to improve my social status and to prove that I am a woman, but I can succeed by learning English then enroll to a good major at the university". Obviously, Saudi females have higher motivation than Saudi male students. Saudi female integrative motivation general means rating is (2.8) and the instrumental general mean rating is (3.01). Saudi female students want to prove to everyone that they are capable of achieving higher positions. Also, they are more motivated than Saudi males because chances in Saudi Arabia for women to obtain a job are lesser than males' chances, which push females to work hard to get a high score to raise their chances of finding a job in the future. On the other hand, Saudi males' general mean integrative motivation is (2.48) and the instrumental motivation is (2.76) which is higher than integrative motivation. One of the Saudi males stated in the interview that

"I am learning English to gain university admission. This is the thing I care about now". Saudi females have had higher motivation rating in all the three types of motivations than male students except the integrative motivation due to their cultural boundaries. The Saudi female students want to prove to everyone that they can achieve higher positions. Also, they are more motivated than the Saudi males.

\subsection{Chinese Females vs. Chinese Males}

Chinese female intrinsic motivations general mean rating is (2.85) and the extrinsic motivation general mean rating is (2.69). The Chinese male intrinsic motivation general mean is (3.17) and the extrinsic motivation general mean is (3.02). In the Chinese case the male obtains higher extrinsic and extrinsic motivation than female. 


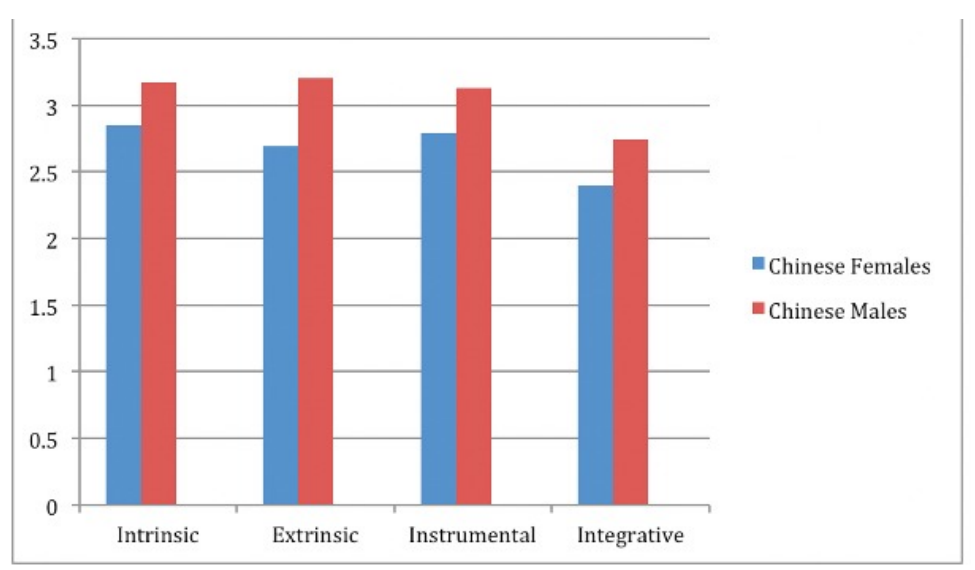

Figure 5. Mean Average: Chinese Females and Males Motivation Types

In the interview, a Chinese female exchange student stated, "I found learning English in U.S is not hard. I like the life here in the US, but I want to go back to China and study there".

Chinese females are more attached to life in China than Chinese males, which was clear when I was interviewing them. They are more attached to their country than males which were evident in their interview answers. The female integrative motivation rating is (2.4) and the instrumental motivation general rating is (2.79). On the other hand, the Chinese male integrative motivation rating is (2.74) and the instrumental motivation general rating is (3.13). Also, males obtain higher instrumental and integrative motivation than females. Male Chinese students are more interested in learning English and settle abroad more than female students, which enhances their attitude toward English.

\section{Conclusion and Discussion}

This research investigated the types of the motivation that Chinese and Saudi EFL learners have for learning the second language. Both groups have extrinsic and intrinsic motivation as well integrative and instrumental motivation which is aligned with other studies. The Chinese group intrinsic motivation is stronger than the extrinsic motivation. On the other hand, Saudi participants also have both motivations to learn English, but they are the opposite of Chinese motivations. Saudi students' extrinsic motivation is greatly higher than their intrinsic motivation. In China, the strong English teaching supports the students to adopt intrinsic and integrative motivation. As well, the nature of their lives and their culture is parallel to the nature of the life abroad which makes the Chinese learners adopt integrative and intrinsic motivation.

Furthermore, the social status differences between Saudi and Chinese learners are crucial aspects. Saudi learners typically more involved with their families than Chinese leaners, which reduces the Saudi learners' chances to have an English speaker roommate or partner. These reasons decrease the Saudi students' contact with the L2 community and restrict their social lives communication, which make them adopt extrinsic and instrumental motivation rather than the intrinsic or integrative motivation.

Therefore, both groups have integrative and instrumental motivation. Saudi students' instrumental motivation is higher than the integrative motivation. However, Chinese students' integrative motivation is almost the same as their instrumental motivation. In sum, Chinese students have strong intrinsic, extrinsic, integrative, and instrumental motivation toward learning English. However, Saudi students have extrinsic and instrumental motivation stronger than other types of motivation. It indicates that Chinese students learning of English is directed by internal and external reasons, which help them to sustain long term run. However, Saudi students are directed by external reward rather than internal reasons, which make their learning of English less effective. Moreover, their English learning backgrounds differ from Chinese English backgrounds. Saudis start learning English in the fourth grade which is considered late compared to the Chinese group who start earlier. In addition, in Saudi Arabia there is no intensive teaching of English in school like in China. The intensive teaching of the English four skills in China helps the students to adopt intrinsic and integrative motivation. Also, the nature of their lives and their culture is similar to the nature of life abroad which makes the Chinese students adopt integrative and intrinsic motivation higher than the Saudi students.

Moreover, the gender role plays an important role in defining their type of motivation. Saudi females have stronger intrinsic, extrinsic, and instrumental motivation than Saudi males. On the other hand, Chinese males have stronger intrinsic, extrinsic, integrative, and instrumental motivation than female Chinese. This result indicated that gender in certain groups differ from gender from other groups due to social and cultural factors. 
Teachers and instructors need deep investigation about the Saudi and Chinese types of motivations, their group differences, and their gender differences in order to deal with them significantly and to facilitate teachers' understanding of the ways that can increase their motivation. The results of this study can give the teachers a hint about what each group's goal from learning English is directed to, internal or external rewards. Teachers can help the Saudi students by providing them with the materials they need to achieve their external goal. However, they must integrate the Saudi students with some materials that train them to interact with L2 more and provide them with the materials that satisfy their needs.

Teachers should consider these differences and try to encourage them to speak and participate until they are used to this new environ. Saudi females are not used to study with male students, which might demotivate them in class. Teachers should consider these differences and try to encourage them to speak and participate until they used to this new environment. Also, teacher can provide the Saudi students with native conversations partners which might make the more integrated to the target community.

Also, teachers can provide the Saudi students with online native conversation partners which might make them more integrated to the target language. A teacher might offer for their students opportunities to collaboratively participate in experiments, role-playing, simulations, educational games, and creative applications of what is being learned. Also, they can make the students interact with their peers and increase the activities that allow interaction with their peers. Lastly, this research was time consuming. There was no time to observe the participants attitude toward English in class and out class which affected their type of motivation. It remains the subject of future research to investigate in depth about the reasons that make each group adopt a certain different type of motivation than other groups.

\section{References}

Al-Jarf, R. (2008). The Impact of English as an International Language (EIL) upon Arabic in Saudi Arabia. Asian EFL Journal, 10(4), 193-210.

Al-Mubireek, S. (2020). Teacher Perceptions of the Effectiveness of Using Handheld Devices in Saudi EFL Classroom Practices. International Journal of Emerging Technologies in Learning (iJET), 15(22), 204. https://doi.org/10.3991/ijet.v15i22.16689

Alresheedi, H. (2014). Motivation of Female Students Learning English as A Foreign Language at Qassim University.

Batubara, F., Derin, T., Putri, N. S., \& Yudar, R. S. (2020). Five Factors Influencing the Students' Motivation to Learn English as a Foreign Language: A Closer Look into Montessori Classroom Environment. REiLA: Journal of Research and Innovation in Language, 2(2), 76-84. https://doi.org/10.31849/reila.v2i2.3165

Daguo, L. (2006). Motivation in Second Language Acquisition in Chinese Research Students in the UK. Evaluation \& Research In Education, 19(1), 38-58. https://doi.org/10.1080/09500790608668324

Daif-Allah, A. (2012). Beliefs about Foreign Language Learning and Their Relationship to Gender. English Language Teaching, 5(10), 20-33. https://doi.org/10.5539/elt.v5n10p20

Daif-Allah Ayman, \& Aljumah Fahad. (2020). Differences in Motivation to Learning English among Saudi University Students. English Language Teaching, 13(2), 63. https://doi.org/10.5539/elt.v13n2p63

Kissau, S. (2006). Gender differences in second language motivation: An investigation of micro and macro-level influences. Canadian Journal Of Applied Linguistics, 9(1), 73-96.

Kormos, J., Kiddle, T., \& Csizér, K. (2011). Systems of Goals, Attitudes, and Self-related Beliefs in Second Language-Learning Motivation. Applied Linguistics, 32(5), 495-516. https://doi.org/10.1093/applin/amr019

Lei, Z. (2012). Chinese Non-English Majors. English Language Teaching, 5(3), 100-122. https://doi.org/10.5539/elt.v5n3p100

Maherzi, S. (2011). Perceptions of classroom climate and motivation to study English in Saudi Arabia: Developing a questionnaire to measure perceptions and motivation. Electronic Journal of Research In Educational Psychology, 9(2), 765-798. https://doi.org/10.25115/ejrep.v9i24.1473

Meihua, L. (2012). Motivation in Chinese University EFL Learners in Varying Learning Contexts. TESL Reporter, 45(2), 17-39.

Midraj, S., Midraj, J., O'Neill, G., \& Sellami, A. (2008). The Affective Factors and English Language Attainment of Arab EFL Learners. International Journal of Applied Educational Studies, 1(1), 43-52. 
Negueruela-Azarola, E. (2011). Changing reasons as reasoning changes: a narrative interview on second language classroom motivation, telecollaboration, and the learning of foreign languages. Language Awareness, 20(3), 183-201. https://doi.org/10.1080/09658416.2011.570348

Noels, K. A., Pelletier, L. G., Clément, R., \& Vallerand, R. J. (2003). Why Are You Learning a Second Language. Motivational Orientations and Self-Determination Theory. Language Learning, 53(S1), 33-64. https://doi.org/10.1111/1467-9922.53223

Rubenfeld, S., Sinclair, L., \& Clément, R. (2007). Second language learning and acculturation: The role of motivation and goal content congruence. Canadian Journal of Applied Linguistics, 10(3), 308-322.

Siemon, A. (2010). Learning English In China: Is Language Teaching a Reality Practically Primary.

Wan-Er, Z. (2008). Motivation and language learning in the context of China. Sino-US English Teaching, 5(4), $7-11$.

Wang, F. (2008). Motivation and English Achievement: An Exploratory and Confirmatory Factor Analysis of a New Measurement for Chinese Students of English Learning. North American Journal of Psychology, 10(3), 633-646.

Yan, W. (2010). A Survey of the Foreign Language Learning Motivation among Polytechnic Students in China. Journal Of Language Teaching \& Research, 1(5), 605-613. https://doi.org/10.4304/j1tr.1.5.605-613 


\section{Appendix}

(A)

1. I love learning English without a specific reason. 我就单纯䓀次学英语, 没有什么特侏的理由

2. I want to learn English because I am interested in learning this language. 我学英语的理由就是我划它感等趣

3. I mainly learn English because I like this language. 我主要是因为喜欢这门语䛔学习英语的

4. I like watching movies, shows, and songs in English which pushed me to learn English. 我喜欦看英文电景和电视节 目、以及听英文听歌曲，这些是我学 英文的动力

5. I love English literature which pushed me to learn English. 我暿煐语文学，它是我学英文的动力

6. I am learning English to know more about American culture and history. 我学英敔的目的是䟄深入了解美国的历史文化

7. Before enrolling to the university, I was learning English for a reason which is gaining the university admission. 在来这里读大学前, 我学英文是为了获得进入这所大学的资格

8. After entering the university, my purpose of learning English is to get high grades in English classes. 进入大学 后，我学英浯的目的是为了拿更高的成绩

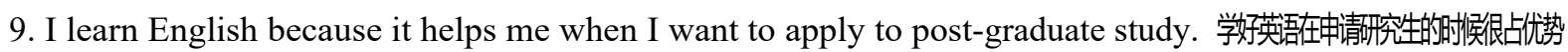

10. The best thing about learning English is to gain a university admission. 学英咟的主要目标就是获得大学申请资格

11. I am learning English because it is a core subject in my course. 我学英语是因为它是一门重要课程

12. My parents push me to learn English. 我父母珴学习英语

13. I am learning English because it facilitates the learning of other subjects. 学好英语, 其他课程学习也会受益

14. I am learning English because I want to pursue all my graduate studies abroad. 我为了出国渎形究生而学习英语

15. I learn English because it well helps me when I travel abroad. 我学英珸为了出行 (旅斿) 方便

16. I am learning English to build friendships with English natives. 我学英珸是为了与美国人建立友谊

17. I want to learn English for immigration purposes. 为了移民，我学习英语

18. I am going to continue learning English because I will not find a job if I don't improve my language. 我 会断卖学英语不然 (以我现在的水平) 我会找不到工作

19. I am studying English to get promotions when I get a job. 学习英语为了工作中获得㬐升

20. I really believe English is the greatest language in the world. 我真的议为英语是全世界独一无一的语言

21. I think learning English is very important because it helps me to communicate greatly in the contemporary world. 我认为学习英语很重要，因为当今社会我们基本靠英语交流

22. I believe learning English is considered the first step to success 我相煐语是成功路上的高门砖

23. If I learn English, I will satisfy my parents very much. 父母会因为我学习英语而高兴

(B)

\begin{tabular}{|c|c|c|c|c|c|}
\hline \multirow[t]{2}{*}{ Items of Intrinsic Motivation } & \multicolumn{4}{|c|}{$\left|\begin{array}{l}\text { Frequency of Students' } \\
\text { Responses (24 students) }\end{array}\right| \lambda$} & \multirow[t]{2}{*}{ SD } \\
\hline & 1 & 2 & 3 & 4 & \\
\hline 1- I love learning English without a specific reason. & 2 & 7 & 1 & 1 & \\
\hline 2- I want to learn English because I am interested in learning this language. & 3 & 7 & 1 & 0 & \\
\hline 3- I mainly want learn English because I like this language. & 3 & 5 & 3 & 0 & \\
\hline $\begin{array}{l}\text { 4- I like watching movies, shows, and songs in English which pushed me to } \\
\text { learn English. }\end{array}$ & 3 & 8 & 0 & 0 & \\
\hline 5- I love English literature which pushed me to learn English. & 0 & 4 & 7 & 0 & \\
\hline $\begin{array}{l}\text { 26- I learn English because by learning English I feel I am achieving a great } \\
\text { thing }\end{array}$ & 1 & 9 & 1 & 0 & \\
\hline 28- I learn English to have a new challenge in my life. & 4 & 6 & 1 & 0 & \\
\hline
\end{tabular}




\begin{tabular}{|c|c|c|c|c|c|c|}
\hline \multicolumn{7}{|l|}{ General Mean } \\
\hline \multirow[t]{2}{*}{ Items of Extrinsic Motivation } & \multicolumn{5}{|c|}{$\left|\begin{array}{l}\text { Frequency of Students' } \\
\text { Responses ( } 24 \text { students) }\end{array}\right|$} & \multirow[t]{2}{*}{ SD } \\
\hline & 1 & 2 & 3 & 4 & & \\
\hline 6- I am learning English to know more about American culture and history. & 1 & 8 & 2 & 0 & & \\
\hline $\begin{array}{l}\text { 7- Before enrolling to the university, I was learning English for a reason which } \\
\text { is gaining the university admission. }\end{array}$ & 3 & 6 & 2 & 0 & & \\
\hline $\begin{array}{l}\text { 8- After entering the university, my purpose of learning English is to get high } \\
\text { grades in English classes. }\end{array}$ & 2 & 5 & 3 & 1 & & \\
\hline $\begin{array}{l}\text { 9- I learn English because it well helps me when I want to apply to } \\
\text { post-graduate study. }\end{array}$ & 3 & 7 & 0 & 1 & & \\
\hline 10- The best thing about learning English is to gain a university admission. & 3 & 3 & 5 & 0 & & \\
\hline 11- I am learning English because it is a core subject in my course. & 3 & 6 & 2 & 0 & & \\
\hline 12- My parents push me to learn English. & 1 & 5 & 4 & 0 & & \\
\hline 13- I am learning English because it facilitates the learning of other subjects. & 1 & 8 & 2 & 0 & & \\
\hline $\begin{array}{l}\text { 14- I am learning English because I want to pursue all my graduate studies } \\
\text { abroad. }\end{array}$ & 3 & 4 & 3 & 0 & & \\
\hline 15- I learn English because it well helps me when I travel abroad. & 4 & 7 & 0 & 0 & & \\
\hline 16- I am learning English to build friendships with English natives. & 3 & 7 & 1 & 0 & & \\
\hline 17- I want to learn English for immigration purposes. & 0 & 2 & 6 & 3 & & \\
\hline $\begin{array}{l}\text { 18- I am going to continue learning English because I will not find a job if I } \\
\text { don't improve my language. }\end{array}$ & 2 & 5 & 4 & 0 & & \\
\hline 19- I am studying English to get promotions when I get a job. & 3 & 6 & 2 & 0 & & \\
\hline 20- I really believe English is the greatest language in the world. & 0 & 2 & 9 & 0 & & \\
\hline $\begin{array}{l}\text { 21- I think learning English is very important because it helps me to } \\
\text { communicate greatly in the contemporary world. }\end{array}$ & 4 & 7 & 0 & 0 & & \\
\hline 22- I believe learning English is considered the first step to success & 1 & 6 & 4 & 0 & & \\
\hline 23- If I learn English, I will satisfy my parents very much. & 0 & 7 & 4 & 0 & & \\
\hline $\begin{array}{l}\text { 24- My goal from learning English is to know more about the sciences and } \\
\text { technology developments. }\end{array}$ & 0 & 6 & 5 & 0 & & \\
\hline $\begin{array}{l}\text { 25- I mainly learn English to make other countries know more about my } \\
\text { country and culture. }\end{array}$ & 0 & 6 & 9 & 0 & & \\
\hline 27- I believe learning English is considered the first step to success & 2 & 5 & 4 & 0 & & \\
\hline \multicolumn{7}{|l|}{ General Mean } \\
\hline \multirow[t]{2}{*}{ Items of Integrative Motivation } & \multicolumn{5}{|c|}{$\mid \begin{array}{l}\text { Frequency of Students' } \\
\text { Responses ( } 24 \text { students) }\end{array}$} & SD \\
\hline & 1 & 2 & 3 & 4 & & \\
\hline 6- I am learning English to know more about American culture and history & 1 & 8 & 2 & 0 & & \\
\hline $\begin{array}{l}\text { 14- I am learning English because I want to pursue all my graduate studies } \\
\text { abroad. }\end{array}$ & s 3 & 4 & 3 & 0 & & \\
\hline 17- I want to learn English for immigration purposes. & 0 & 2 & 6 & 3 & & \\
\hline 20- I really believe English is the greatest language in the world. & 0 & 2 & 9 & 0 & & \\
\hline 27- To be a good speaker of English means you are a well-educated. & 2 & 5 & 4 & 0 & & \\
\hline
\end{tabular}




\begin{tabular}{|c|c|c|c|c|c|c|}
\hline General Mean & & & & & & \\
\hline \multirow[t]{2}{*}{ Items of instrumental Motivation } & \multicolumn{5}{|c|}{$\begin{array}{l}\text { Frequency of Students' } \\
\text { Responses (24 students) }\end{array}$} & SD \\
\hline & 1 & 2 & 3 & 4 & & \\
\hline $\begin{array}{l}\text { 7- Before enrolling to the university, I was learning English for a reason which } \\
\text { is gaining the university admission. }\end{array}$ & 3 & 6 & 2 & 1 & & \\
\hline $\begin{array}{l}\text { 8- After entering the university, my purpose of learning English is to get high } \\
\text { grades in English classes. }\end{array}$ & 2 & 5 & 3 & 1 & & \\
\hline $\begin{array}{l}\text { 9- I learn English because it well helps me when I want to apply to } \\
\text { post-graduate study. }\end{array}$ & 3 & 7 & 0 & 1 & & \\
\hline 10- The best thing about learning English is to gain a university admission. & 3 & 3 & 5 & 0 & & \\
\hline 13- I am learning English because it facilitates the learning of other subjects. & 1 & 8 & 2 & 0 & & \\
\hline 15- I learn English because it well helps me when I travel abroad. & 4 & 7 & 0 & 0 & & \\
\hline
\end{tabular}

(C)

Females and Males

\begin{tabular}{|c|c|c|c|c|c|}
\hline \multirow[t]{2}{*}{ Items of Intrinsic Motivation } & \multicolumn{4}{|c|}{\begin{tabular}{|l|l|} 
Frequency of Students' \\
Responses (24 students)
\end{tabular}} & \multirow[t]{2}{*}{$\mathrm{SD}$} \\
\hline & 1 & 2 & 3 & 4 & \\
\hline 1- I love learning English without a specific reason. & 1 & 5 & 2 & 1 & \\
\hline $\begin{array}{l}\text { 2- I want to learn English because I am interested in learning this } \\
\text { language. }\end{array}$ & 3 & 4 & 2 & 0 & \\
\hline 3- I mainly want learn English because I like this language. & 1 & 5 & 3 & 0 & \\
\hline $\begin{array}{l}\text { 4- I like watching movies, shows, and songs in English which pushed } \\
\text { me to learn English. }\end{array}$ & 5 & 3 & 1 & 0 & \\
\hline 5- I love English literature which pushed me to learn English. & 0 & 2 & 6 & 1 & \\
\hline $\begin{array}{l}\text { 26- I learn English because by learning English I feel I am achieving a } \\
\text { great thing. }\end{array}$ & 2 & 4 & 3 & 0 & \\
\hline 28- I learn English to have a new challenge in my life. & 2 & 4 & 3 & 0 & \\
\hline \multicolumn{6}{|l|}{ General Mean } \\
\hline \multirow[t]{2}{*}{ Items of Extrinsic Motivation } & \multicolumn{4}{|c|}{\begin{tabular}{|l|l|} 
Frequency of Students' \\
Responses (24 students)
\end{tabular}} & SD \\
\hline & 1 & 2 & 3 & 4 & \\
\hline $\begin{array}{l}\text { 6- I am learning English to know more about American culture and } \\
\text { history. }\end{array}$ & 0 & 6 & 2 & 1 & \\
\hline $\begin{array}{l}\text { 7- Before enrolling to the university, I was learning English for a } \\
\text { reason which is gaining the university admission. }\end{array}$ & 1 & 3 & 5 & 0 & \\
\hline $\begin{array}{l}\text { 8-After entering the university, my purpose of learning English is to } \\
\text { get high grades in English classes. }\end{array}$ & 0 & 9 & 0 & 0 & \\
\hline $\begin{array}{l}\text { 9- I learn English because it well helps me when I want to apply to } \\
\text { post-graduate study. }\end{array}$ & 1 & 8 & 0 & 0 & \\
\hline $\begin{array}{l}\text { 10- The best thing about learning English is to gain a university } \\
\text { admission. }\end{array}$ & 1 & 4 & 4 & 0 & \\
\hline
\end{tabular}




\begin{tabular}{|c|c|c|c|c|c|c|}
\hline 11- I am learning English because it is a core subject. & 2 & 3 & 4 & 0 & & \\
\hline 12- My parents push me to learn English. & 3 & 3 & 2 & 0 & & \\
\hline $\begin{array}{l}\text { 13- I am learning English because it facilitates the learning of other } \\
\text { subjects. }\end{array}$ & 1 & 6 & 2 & 0 & & \\
\hline $\begin{array}{l}\text { 14- I am learning English because I want to pursue all my graduate } \\
\text { studies abroad. }\end{array}$ & 4 & 2 & 3 & 0 & & \\
\hline 15- I learn English because it well helps me when I travel abroad. & 3 & 3 & 3 & 0 & & \\
\hline 16- I am learning English to build friendships with English natives. & 0 & 3 & 6 & 0 & & \\
\hline 17- I want to learn English for immigration purposes. & 0 & 1 & 8 & 0 & & \\
\hline $\begin{array}{l}\text { 18- I am going to continue learning English because I will not find a } \\
\text { job if I don't improve my language. }\end{array}$ & 1 & 7 & 1 & 0 & & \\
\hline 19- I am studying English to get promotions when I get a job. & 1 & 6 & 2 & 0 & & \\
\hline 20- I really believe English is the greatest language in the world. & 0 & 5 & 4 & 0 & & \\
\hline $\begin{array}{l}\text { 21- I think learning English is very important because it helps me to } \\
\text { communicate greatly in the contemporary world. }\end{array}$ & 3 & 4 & 2 & 0 & & \\
\hline 22- I believe learning English is considered the first step to success. & 3 & 5 & 1 & 0 & & \\
\hline 23- If I learn English, I will satisfy my parents very much. & 1 & 4 & 4 & 0 & & \\
\hline $\begin{array}{l}\text { 24- My goal from learning English is to know more about the } \\
\text { sciences and technology developments. }\end{array}$ & 2 & 3 & 4 & 0 & & \\
\hline $\begin{array}{l}\text { 25- I mainly learn English to make other countries know more about } \\
\text { my country and culture. }\end{array}$ & 3 & 2 & 4 & 0 & & \\
\hline 27- I believe learning English is considered the first step to success. & 1 & 5 & 3 & 0 & & \\
\hline \multicolumn{7}{|l|}{ General Mean } \\
\hline \multirow[t]{2}{*}{ Items of Integrative Motivation } & \multicolumn{4}{|c|}{$\begin{array}{l}\text { Frequency of } \text { Students' } \\
\text { Responses (24 students) }\end{array}$} & & SD \\
\hline & 1 & 2 & 3 & 4 & & \\
\hline $\begin{array}{l}\text { 6- I am learning English to know more about American culture } \\
\text { history }\end{array}$ & 0 & 6 & 2 & 1 & & \\
\hline
\end{tabular}

\section{Copyrights}

Copyright for this article is retained by the author(s), with first publication rights granted to the journal.

This is an open-access article distributed under the terms and conditions of the Creative Commons Attribution license (http://creativecommons.org/licenses/by/4.0/). 